\title{
ASSESMENT OF CONVENTION PARTICIPANTS' SATISFACTION TOWARDS THE IMPROVEMENT OF BUSINESS TOURISM OFFER: A CASE STUDY OF ISTRIA, CROATIA
}

\author{
Daniela Gračan \\ Marina Barkiđija Sotošek \\ Rea Matošević
}

https://doi.org//10.20867/tosee.06.21

\begin{abstract}
Purpose - of this paper is to analyze participants' profiles (characteristics) and level of their satisfaction with the offer provided in a destination. Convention tourism is extremely useful and has a number of impacts on the economy of a particular destination as well as the country.

Methodology - The empirical research was concerned with exploring trends in convention tourism. The research was conducted in two convention hotels in Poreč using the survey method from 24 to 27 April 2019 and 120 properly filled questionnaires were collected.

Findings - Most of the subjects were satisfied with the audiovisual equipment of the hall, quality of the exhibitors at the convention, convention program and the comfort of the hall, accessibility of the destination, the attractions in the destination, the additional content and the value for money. Participants were not satisfied with the schedule of the event and level of use of technology during the convention, which certainly points to necessary changes in the convention itself.

Contribution - Conventions have an impact on the development of tourism by increasing offseason movements and creating a new image of Istria so the results of this paper could be valuable to the Istrian tourism board but also to the hotels and other facilities who are trying to profit from the convention tourism.
\end{abstract}

Keywords: Tourism Markets, Business Tourism, Congress Tourism Participants, Tourism Trends, Tourism Requirements.

\section{INTRODUCTION}

Business tourism is considered one of the most profitable special interest tourism. Financial indicators have recorded a significant increase in recent years. Business tourism is growing in parallel with the prominent process of urbanization, global economy and societies with an objective need for a wide exchange of knowledge, information and achievements through meetings and organized scientific, expert meetings and business events (Geić 2011, 332).

In today's world, there is no longer a sharp line between tourist and business travel. According to the UNWTO (2006) definition, business trips that are not related to the activities for which the fee is paid in the place they visit are considered tourism. The travelers who visit the destination for recreation may also make some business contacts, while on the other hand, the business travelers find some time to explore the city, participate in various activities or relax. Business trips are sometimes organized to 
ToSEE - Tourism in Southern and Eastern Europe, Vol. 6, pp. 315-327, 2021.

D. Gračan, M. Barkiđija Sotošek, R. Matošević: ASSESMENT OF CONVENTION PARTICIPANTS' ...

accomplish a specific task, sometimes to train the participant to do their job better and more efficiently, while some trips can be an award from the employer for a good performance. The destination of business tourism is often a destination for holidays, which means that business travelers often use the same transportation, accommodations, food, and other services as tourists who come to the destination for vacation. However, for a destination to become a business destination, it must emphasize certain group factors in addition to attractive, comfortable, and communicative elements. These factors are material and technological resources and specialized convention staff.

Swarbrooke and Horner $(2001,3)$ consider that the terms "business travel" and "business tourism" often identify, but there is a difference between them. Business tourism is a wider concept and encompasses all aspects of business participant experience while the business trip is more focused on just moving a business traveler from one place to another and includes people traveling on a daily basis for business reasons.

Figure 1: MCCI industry within the tourism sector

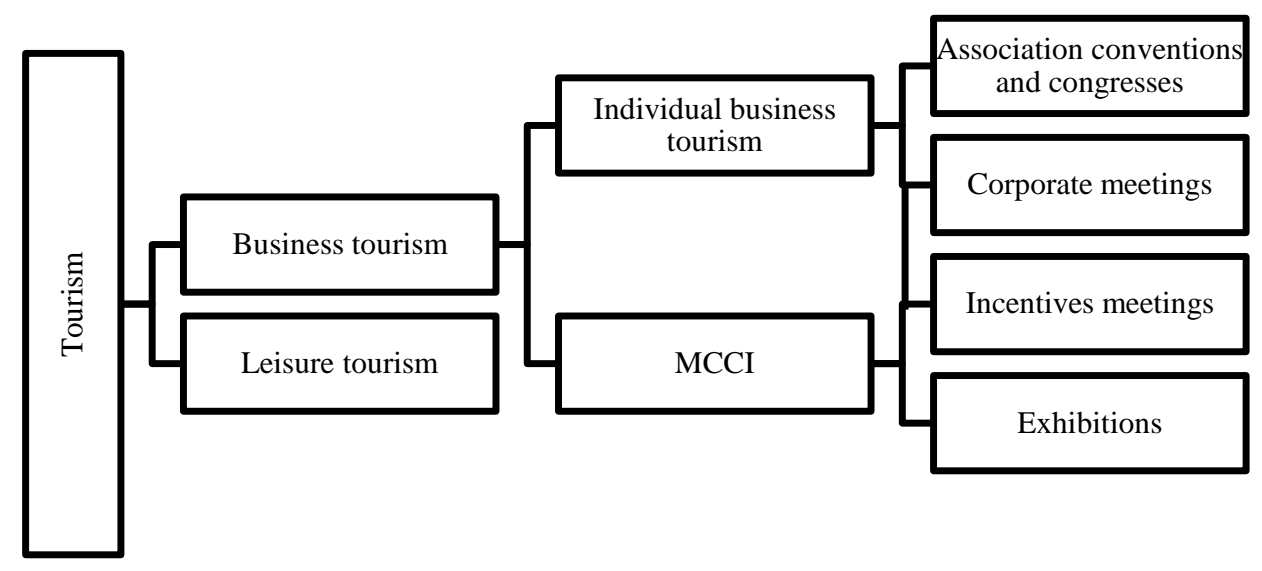

Source: UNWTO and ETC 2015: 15

Business tourism is often replaced by the acronym MICE (Meetings, Incentives, Congress \& Conventions, Exhibition \& Events). The industry MICE is a dynamic phenomenon with numerous operational or associative structures between professionals; organizations such as Convention Bureaus represent the most common associative structure found anywhere (Virgil and Popsa 2014). In the more recent, globally recognized literature published by the World Tourism Organization and European Travel Commission (UNWTO and ETC 2015, 15), the acronym MICE is replaced by the term MCCI. The Meetings, Congresses, Conventions and Incentives industry is part of the larger tourism sector and includes three distinct segments: association meetings and conventions, corporate meetings and corporate incentive programs. Today, the MCCI industry is gaining recognition and market share worldwide. Destinations increasingly understand the importance of hosting business meetings as they are an important form of global engagement - both economically and intellectually. MCCI is thus becoming a part of economic development strategies. Understanding what key trends and players are 
ToSEE - Tourism in Southern and Eastern Europe, Vol. 6, pp. 315-327, 2021.

D. Gračan, M. Barkiđija Sotošek, R. Matošević: ASSESMENT OF CONVENTION PARTICIPANTS' ...

influencing the industry is critical to developing better services that meet the needs of the ever-changing environment (UNWTO and ETC 2015, 24).

An increasingly complex business environment creates more and more challenges. Considering the current trend of significant decrease of participants at individual conventions, understanding the evaluations of convention attendees becomes more important than ever (Gračan et al. 2021). Business travelers are discerning guests with a high paying power. They are customers who expect accurate, reliable, high-quality and flexible services for their money and time. They expect elasticity from service providers when travel changes are required or when there are flight changes, shortening or lengthening of stay, etc. Since attendees of conventions and other business gatherings are exempt from the cost of transportation, meals, and lodging, this reflects the amount of money they spend in the destination. Business travelers use high category hotels, meals, air transportation, individual transfers, and various on-site amenities. Business tourists are more inclined to "out-pay" expenses, as basic travel costs are funded by employers, and for this reason the organizers of such trips have higher incomes.

Business tourism has the characteristic of sustainability, as business trips in most cases take place outside the tourist season, thus increasing capacity utilization. Business tourism also encourages new investments; the improvement of existing infrastructure or the construction of new capacities of convention centers and hotels.

\section{THE ROLE AND IMPORTANCE OF BUSINESS TOURISM FOR THE DEVELOPMENT OF DESINATION}

Business tourism is a very lucrative segment of the tourism supply, so many destinations are turning towards it because of the various advantages that business tourism has over leisure tourism. According to the report of International Congress and Convention Association - ICCA, business and convention tourism, including MICE tourism, accounts for almost a quarter of total international tourism in arrivals and foreign exchange inflows (Soldić 2015). Such a large share should not be ignored, especially given the fact that business tourism can influence certain deficits in this industry. Investments in the development of business tourism are necessary for three basic reasons, namely: prolongation of the tourist season, high spending of business guests and strengthening the image of the country (destination) in the world. Business tourism can help reduce seasonality and stabilize the tourist season as it mainly focuses on the offpeak season. It also generates additional income and creates new, permanent jobs that raise the standard of living of the entire destination, benefiting not only those directly involved, but also the local population and tourism in general. A great advantage for hoteliers is the fact that conventions are organized several years in advance, regardless of weather conditions and other external factors, which guarantees high occupancy rates. Another great advantage of convention tourism is the higher consumption of business guests compared to traditional tourists. Moreover, their employers or convention organizers cover the cost of accommodation and meals, leaving them with a higher budget for personal consumption. In addition to higher spending and a longer season, conventions also contribute to the image of the destination. Destination attractiveness refers to the distinctiveness of a destination in the minds of consumers based on positive 
ToSEE - Tourism in Southern and Eastern Europe, Vol. 6, pp. 315-327, 2021.

D. Gračan, M. Barkiđija Sotošek, R. Matošević: ASSESMENT OF CONVENTION PARTICIPANTS' ...

experiences or other recommendations. Thus, the destination is more attractive the more offers are different from the others. Further details for a destination of business travelers are described in the following figure.

\section{Figure 2: Benefits for the destination of business tourists}

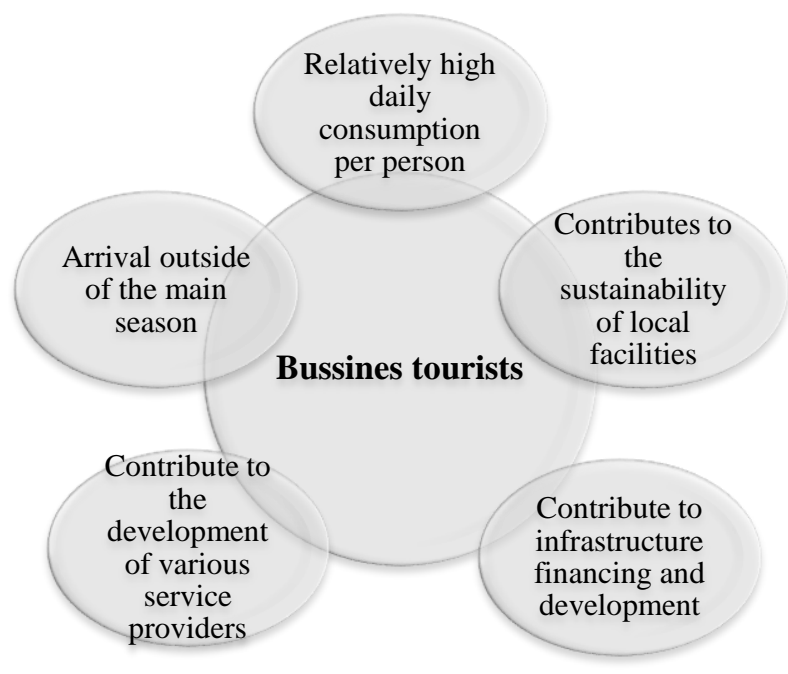

Source: Swarbrooke and Horner $(2001,9)$

From the figure, it can be concluded that the ability to extend the season improves the overall economy and builds a recognizable and positive image in the business tourism market. If the participant has a positive experience, it is very likely that they will choose to return to the private arrangement with family and friends or share their positive experience with their acquaintances. The impact of business tourism on the development of a destination can also be seen in the pre- and post-tourism time that generates additional revenue (e.g. transportation, technical services, car rentals, etc.), through the development of quality services (VIP treatment), development of business tourism through education and training of the workforce, and through the impact on the development of handicrafts and small businesses through increased demand for certain products and services (translation services, catering services, souvenirs, equipment, etc.).

Even though business tourism is the predominant business motive, this does not mean that this segment is decisive in the choice of a destination where a particular convention is held. There are a number of factors that influence it. According to Rogers $(2008,17)$, the conditions for the success of a business-related destination are: attractiveness and image, safety, accessibility, hotel offer, destination content, service quality in the destination, price level in the destination, green destination practices, quality of $\mathrm{DMO} / \mathrm{PCO}$ agencies and convention bureaus, and the availability of different types of business properties. Successful convention destinations are those destinations that meet a large number of the previously mentioned requirements. Strategic planning is a key element that will lead to the desired results. Planning modern and convention centres is 
ToSEE - Tourism in Southern and Eastern Europe, Vol. 6, pp. 315-327, 2021.

D. Gračan, M. Barkiđija Sotošek, R. Matošević: ASSESMENT OF CONVENTION PARTICIPANTS' ...

necessary to make the selected destinations prestigious through large international conventions. In terms of availability, it is important to have good transport links, that is, a greater number of direct flights, flexibility in prices, the possibility of public transport at the destination, shuttle transfers from the hotel to the convention halls and the like.

An important factor is the hotel offer or hotel categorization, which usually varies from three to five star hotels. For the convention participants, adequate technological equipment, additional facilities in the hotel, quality service are required, and more and more attention is paid to the ecological orientation and sustainable management of the hotel. Regarding the variety of offers in the destination, it is important to highlight the gastronomic offer, cultural offer, sports offer, excursion offer and health care as the main factors that will satisfy the leisure time of the convention participants, enrich their experience of the destination and provide a comprehensive picture of their experience. A key factor in selecting a convention destination is the price level of the destination, which is the ratio of value to money spent. Regardless of image, some convention destinations do not necessarily offer a good value for money ratio. The presence of various business properties is also essential. The following factors are important for such facilities: location, technological equipment, multi-functionality, architecture, design, environmental sensitivity and management model. For DMC / PCO agencies and convention bureaus, the main issue is the quality of customer relations. This includes offering value, representing interests, promoting and creating a recognizable and desirable image. It is concluded that convention tourism is extremely beneficial and has a number of impacts on the economy of a particular destination as well as the country.

\section{NEW TRENDS IN BUSINESS TOURISM PARTICIPANTS' EXPECTATIONS}

The basic characteristics of today's tourism are faster, cheaper and easier travel, increasing quality and a diverse range of services. Global tourism trends have been influenced by the generation of post-industrial society through a strong process of changing needs and habits related to accommodation, food, drink, entertainment, pleasure, transportation, etc. (Gračan 2020). These trends include last minute bookings (due to the rise of the internet and budget airlines), shorter and more frequent stays (due to flexible work schedules), the growing proportion of Millennials who are environmentally conscious, reliable transport, good health standards and a clean environment (Evans et al. 2011, 25). Due to an increasing pressure on the tourism industry, which is constantly looking for new systems and technologies to reduce costs, increase revenue and improve the experience for travellers, this need for continuous innovation, investment in technology is becoming increasingly important.

Information technology (IT) will play a major role, but there are other technological innovations and trends to consider in the future, such as use of mobile phones when choosing a destination (exponential growth year on year basis), mobile web applications, micro-segmentation in sales campaigns, personalization to improve the travel experience, virtual offices in tourism through social networks, tablets and smart TV in hotels, a new relationship with the customer, check-in automation through mobile phones, check-out and payments through biometric fingerprints, free $\mathrm{Wi}-\mathrm{Fi}$, socialized hotel guests, expansion of mobile payments, multi-screen consumers, integrated digital 
ToSEE - Tourism in Southern and Eastern Europe, Vol. 6, pp. 315-327, 2021.

D. Gračan, M. Barkiđija Sotošek, R. Matošević: ASSESMENT OF CONVENTION PARTICIPANTS' ...

management, computerized hotel (Virgil and Popsa 2014). The introduction of new technologies such as Voice Recognition Technology would increase the appreciation of the convention by the attendees, such advancement would have changed the industry in various ways. Technology is becoming more social, wearable, predictive and changing the view (Gračan, Barkiđija Sotošek, and Šerić 2018). It enables the use of virtual welcome desks, where attendees can access a range of services without the physical presence of a host, and facial recognition software used for large-scale event registration. Trends suggest that attendees expect convention organizers to map behaviours and preferences onto more and more program elements. Types of activities or characteristics of a destination influence the choice of location and communication campaigns. Tracking clicks on links in emails and program pages will be used to customize gift or activity choices.

Many cities around the world today invest considerable financial resources in their tourism marketing strategies to attract major conventions (Fenich 2016; Crouch 2019). The convention venue is changing. More and more organizers are looking for changes in the design of convention centres. There is also a growing demand for design spaces which includes couches, comfortable chairs and similar furniture. Just as traditional spaces are changing, the combination of interactive and experiential education is no longer a novelty, but a standard. Traditional forms of learning in the form of lectures are easily fading into history. Convention organizers are moving away from one-way, static formats to conversational ones. This could mean incorporating more email, video and webcasting into educational events - a reflection on education as a multimedia, multi-layered experience.

Incorporating healthy alternatives to food and beverage offerings at conferences is not a new phenomenon, but will soon be essential. Conscious food handling and food waste will be on the minds of an ever-increasing number of event organizers and attendees in the coming year. The elimination of single-use plastic packaging shows how quickly something we didn't think about yesterday can become a very important issue. Slowly, traditional conference room settings (cinema, classroom, or U-setting) are being abandoned in favor of a variety of arrangements, such as the front couch, mid-sized conference table, high-backed tables, and backstage space for those who want it. Such a set provides attendees with many options to comfortably accommodate themselves in the room.

\section{ISTRIA AS A COMPETITIVE REGION IN BUSINESS TOURISM}

Istria is the most successful Croatian region, if we look at the tourist results. Moreover, Istria is the first Croatian county that started strategic management of tourism development. Part of its offer also focused on the business segment. The tourist towns of Rovinj, Poreč, Pula, Umag, Novigrad and Vrsar have been developing infrastructure for business tourism for decades and today have a respectable offer. The infrastructure of Rovinj is mainly focused on the convention industry, and is becoming increasingly recognizable among convention organizers and it is gained the trust of various convention participants. 
ToSEE - Tourism in Southern and Eastern Europe, Vol. 6, pp. 315-327, 2021.

D. Gračan, M. Barkiđija Sotošek, R. Matošević: ASSESMENT OF CONVENTION PARTICIPANTS' ...

\section{Table 1: Congress facilities in Istria}

\begin{tabular}{lcc}
\hline & Number of halls & Capacity of the largest hall \\
\hline Kempinski Hotel Adriatic, Savudrija & 14 & 250 \\
Valamar Diamant Hotel, Poreč & 8 & 1000 \\
Hotel Lone, Rovinj & 8 & 650 \\
Sol Umag, Umag & 5 & 120 \\
Park Plaza Histria, Pula & 5 & 700 \\
Melia Coral, Umag & 5 & 350 \\
Hotel Laguna Parentium, Poreč & 5 & 435 \\
Hotel Istra, Rovinj & 5 & 250 \\
Aminess Maestral Hotel, Novigrad & 5 & 180 \\
Villa Polesini, Poreč & 4 & 100 \\
Hotel Villa Letan, Vodnjan & 4 & 120 \\
Hotel Istra Neptun, NP Brijuni & 4 & 400 \\
Valamar Isabella Island Resort, Poreč & 3 & 420 \\
Sol Garden Istra, Umag & 3 & 300 \\
Istarske toplice, Livade & 2 & 150 \\
Hotel Pineta, Vrsar & 2 & 80 \\
Hotel i restoran San Rocco, Brtonigla & 2 & 25 \\
Hotel Eden, Rovinj & 2 & 300 \\
Hotel \& Marina Nautica, Novigrad & 2 & 100 \\
Arcus Residence, Medulin & 2 & 100 \\
Zavičajni muzej Poreštine & 1 & 210 \\
\hline
\end{tabular}

Source: Authors' research and http://www.poslovniturizam.com

Istria County is rich in protected and cultural-historical resources. It is mainly known for its seaside offer, but for decades it has been systematically developing an agrotourist offer in the interior. It offers authentic facilities, luxurious villas and traditional highquality gastronomy.

\section{Graph 1: Congress hotels in Istria by category}

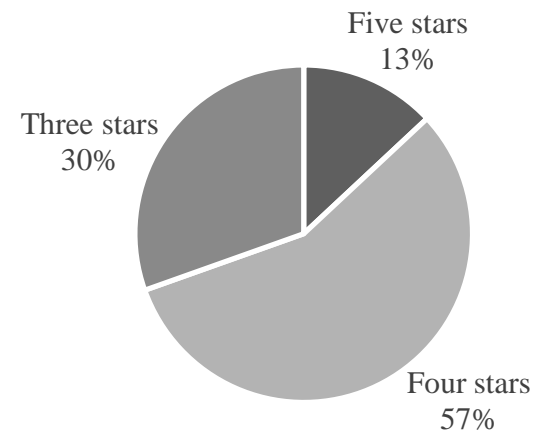

Source: Authors according http://www.croatiameetings.com/searchresults/meeting-venues/region/istria 
ToSEE - Tourism in Southern and Eastern Europe, Vol. 6, pp. 315-327, 2021.

D. Gračan, M. Barkiđija Sotošek, R. Matošević: ASSESMENT OF CONVENTION PARTICIPANTS' ...

Istria does not have a strategy for the development of business tourism as a separate document, but is only mentioned in the Master Plan of Tourism in Istrian County. Although Istria is the region where mass tourism is most developed, the structure of the offer has changed in recent years, a diversified offer is emerging, and business tourism is growing. In further development, it is necessary to focus on strategic goals, such as improving business performance, quality of tourist products, increasing competitiveness in business tourism, exploiting business opportunities and effectively presenting their strengths.

In order to become a competitive region in business tourism, Istria lacks better transport connections between the destinations, more international flights, brand hotels and special convention centres. Due to the underdevelopment of the necessary transport infrastructure, there is a lack of parking spaces and roads in the short-term increase in the number of people. This problem can be solved by proper organization of traffic routing during a particular meeting/convention or by organizing transportation of participants in convention. Moreover, meetings are mostly held in business and convention hotels, with a smaller number of convention centres.

Increasingly sophisticated are museums, galleries, halls of cultural institutions and historical sites. To develop business tourism, there is a need for synergy between business tourism stakeholders and the local community. For example, as part of a convention offering, convention delegates could be taken on tours to experience local attractions and gastronomy, which would also benefit the wider community.

\section{EMPIRICAL RESEARCH OF TRENDS IN CONGRESS TOURISM}

The survey was conducted in two convention hotels in Poreč using the survey method in April 2019 and 120 correctly filled questionnaires were collected. The questionnaire of the survey consisted of questions divided into two parts. The first part of the questions related to topics such as age, gender, place of employment, daily expenditure per person in the destination, length of stay in the destination, days spent in the destination and questions about the use of technology during the convention. The second part of the questions was related to the questions specifically concerning satisfaction with the conditions, the offer of the destination for convention tourism and the importance of the development of convention tourism as a potential product of the tourist offer of Poreč

\subsection{Research results}

After conducting the survey, the obtained data were processed. In terms of age, the majority of respondents are in the range of 25-35 years, 34\% include respondents aged 36-51 years, 13\% include participants between 18 and 24 years, while only $14 \%$ of participants are older than 51 years. Gender structure of the respondents: it is found that $57 \%$ are males and $43 \%$ are females. From the aspect of the field of work or industry in which the respondents are employed, most were employed in engineering and education, law and industry. 
ToSEE - Tourism in Southern and Eastern Europe, Vol. 6, pp. 315-327, 2021.

\section{Graph 2: Work area}

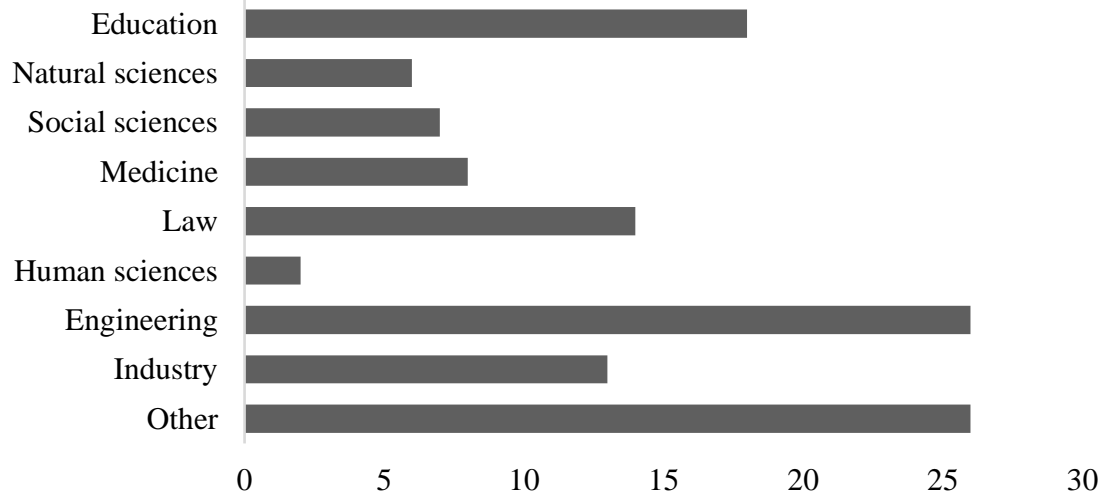

Source: Authors

The most respondents did not extend their stay before or after the congress. Such results can be identified with the fact that there is a lack of additional content so that is why participants do not prolong their stay.

\section{Graph 3: Accommodation in the destination}

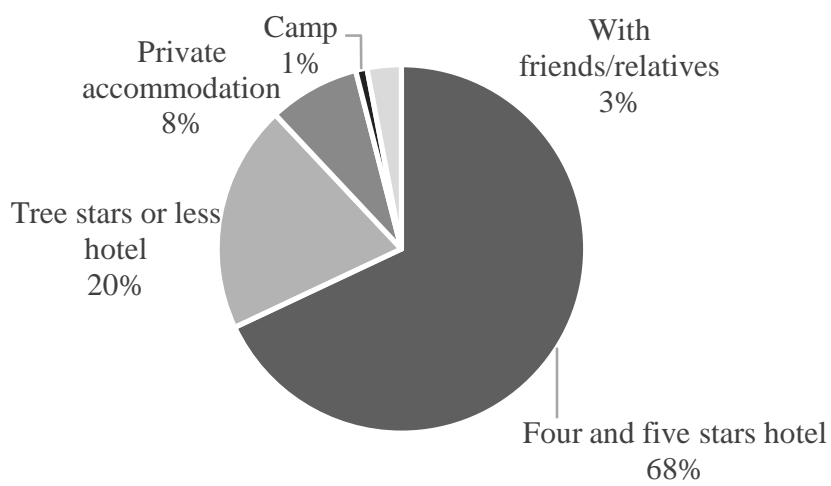

Source: Authors

It can be seen from the figure that majority of the respondents stayed in 4 or 5 star hotels, $68 \%$ of the respondents. A smaller number of respondents stayed in a hotel with 3 stars or less $(20 \%)$ and in private accommodation $(8 \%$ and $3 \%)$, while only $1 \%$ of respondents stayed in camp.

Even $51 \%$ of respondents have visited Poreč several times, $29 \%$ only once and $20 \%$ of respondents never. Moreover, $97 \%$ of the respondents intend to visit Poreč again, while only $3 \%$ do not intend to visit Poreč again. This statistic shows that congress tourism is a good destination promoter. Business travellers often return to the destination. 
ToSEE - Tourism in Southern and Eastern Europe, Vol. 6, pp. 315-327, 2021.

D. Gračan, M. Barkiđija Sotošek, R. Matošević: ASSESMENT OF CONVENTION PARTICIPANTS' ...

Most of the subjects were partly interested and partly satisfied with the audiovisual equipment of the hall, while most of them were completely satisfied with the quality of the exhibitors at the convention. Most feel that the reputation of the convention is excellent and that they are completely satisfied with the convention program and the comfort of the hall. As for the practicality of the schedule, the majority answered this question with an average rating of 3 , meaning they were not satisfied or dissatisfied with this segment. Not rated by the convention participants was the level of use of technology during the convention, which certainly points to necessary changes in the convention itself. In terms of the omnipresent trend of "healthy living", participants would be more pleased if they had the opportunity to have healthy and energy-rich meals during breaks, in addition to the usual pots of coffee or tea.

Table 2: The satisfaction of the participants with the congress program

\begin{tabular}{lc}
\hline Program & Average grade \\
\hline Interesting topic & 4,31 \\
Congress reputation & 4,51 \\
Congress program & 4,56 \\
The quality of exhibitors/speakers & 4,73 \\
Audio-visual equipment & 4,42 \\
The comfort of the hall in the work area & 4,78 \\
The practicality of the date & 3,31 \\
Using technology in the congress program & 1,95 \\
Offering healthy food during the congress & 2,75 \\
\hline
\end{tabular}

Source: Authors

Most respondents were satisfied with the accessibility of the destination, the attractions in the destination, the additional content and the value for money. Most respondents were dissatisfied with the transport links to some extent. It can be assumed that the dissatisfaction is due to an insufficient number of direct flights and poorer transport links in the destination itself. Furthermore, most respondents were completely satisfied with the image of the destination, the safety of the destination, the environmental protection, the hotel offer, the gastronomic offer of the destination and the friendliness of the employees in the destination.

Table 3: The satisfaction of the respondents with the destination

\begin{tabular}{lc}
\hline Destination & Average grade \\
\hline Destination availability & 4,21 \\
Traffic connections in the destination & 2,46 \\
Attractions in the destination & 4,19 \\
Destination image & 4,87 \\
Safety in the destination & 4,66 \\
Hotel content & 4,56 \\
Additional content & 4,21 \\
Gastronomic offer of the destination & 4,54 \\
Environmental preservation & 4,67 \\
The kindness of the employees in the destination & 4,90 \\
Price and quality ratio & 3,89 \\
\hline
\end{tabular}

Source: Authors 
ToSEE - Tourism in Southern and Eastern Europe, Vol. 6, pp. 315-327, 2021.

D. Gračan, M. Barkiđija Sotošek, R. Matošević: ASSESMENT OF CONVENTION PARTICIPANTS' ...

In terms of cost, most respondents were partially satisfied with the cost of transportation and registration and completely satisfied with the cost of accommodation. A large number of respondents were fully satisfied with outdoor activities, such as visiting the surrounding area and the range of excursions on offer, and partially satisfied with the range of sporting activities on offer. Most of the respondents did not visit friends or relatives and did not visit the city with their family or friends. The variety of content for entertainment was rated by the majority of respondents with an average rating of 3 , meaning that they were neither satisfied nor dissatisfied.

\section{Graph 4: The reason for the participants' participation at the congress}

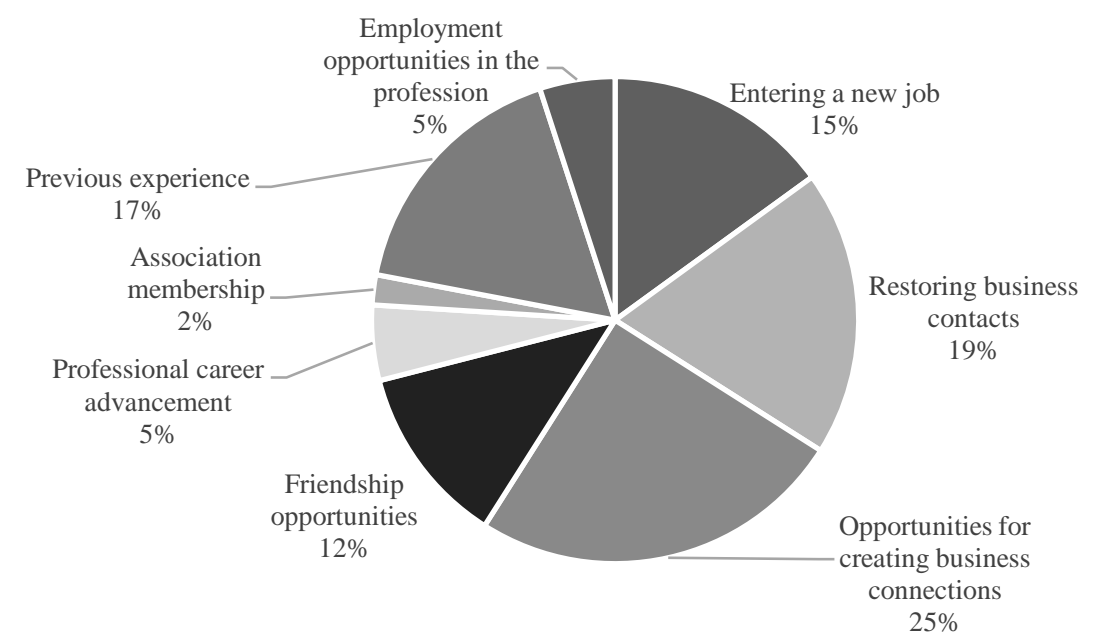

Source: Authors

The figure shows that the largest number of respondents participated in the convention because of the possibility of creating business connections, and the smallest number participated because of participation/membership in the association. Furthermore, a large number of respondents participated in the convention because of the renewal of business contacts they had previously established. Previous experience has also played a major role in convention selection, so even $17 \%$ of respondents answered that it was precisely on the basis of previous experience that they decided to take part in the congress. Only $5 \%$ of the respondents decided to take part in the convention because of employment opportunities in the profession (unemployed) and professional advancement in the career (employed).

\subsection{Discussion}

It can be concluded that the city of Poreč has a great potential for the development of congress tourism. The location, attractiveness and safety of the destination contribute to its future development. The wide range of congress hotels offers a great choice for holding conventions and other business events. The destination also includes a meaningful tourist offer with cultural, entertainment and dining facilities, that are not 
ToSEE - Tourism in Southern and Eastern Europe, Vol. 6, pp. 315-327, 2021.

D. Gračan, M. Barkiđija Sotošek, R. Matošević: ASSESMENT OF CONVENTION PARTICIPANTS' ...

lacking in the destination. In addition to the destination, the content and form of the convention is also important. The convention needs to be adapted to the specific needs of business guests by incorporating technology and creating a more flexible schedule for participants.

\section{CONCLUSION}

Business tourism and all related facilities are very important for the future tourism development of the destination, especially when it comes to large conventions that generate significant revenue. When planning an adequate convention infrastructure, the size of the convention is important. To improve convention tourism, it is necessary to build new convention centers and renovate existing facilities in hotels. By organizing business meetings, high economic effects are achieved and influential visitors are attracted.

Conventions have an impact on the development of tourism by increasing off-season movements and creating a new image of Istria. Istria has built its image as a holiday destination focused on sun and sea as the primary tourist product, and has only recently been defined as a convention destination. More investment in convention infrastructure and transport links is needed to form a convention offer enriched with additional amenities that will attract a larger number of convention tourists. The problem still lies in a limited number of direct flights, as Istria is close to the broadcast market and has the potential for better transport connections. Connecting convention infrastructure, convention offices, convention organizers and additional content to the destination will contribute to a higher quality convention tourism product and thus increase the number of participants. Feedback from convention participants is positive and a large number of participants return to the destination year after year.

One of the most important suggestions for future research is to repeat this research during the COVID -19 crisis, as the motives and preferences of convention participants are different now than when this research was conducted (one year before the coronavirus). Since the epidemiological situation is completely different now than it was in 2019, it is believed that it will be difficult to compare the responses of the then and current research.

\section{REFERENCES}

Crouch, G. I., Del Chiappa, G. and Perdue, R.R. (2019), "International convention tourism: A choice modelling experiment of host city competition", Tourism Management, Vol. 71, pp. 530-542. doi: 10.1016/j.tourman.2018.10.002

Evans, N., Campbel, N. and Stonehouse, G. (2011), Strategic Management for Travel and Tourism, Taylor \& Francis, London.

Fenich, G. (2016), Meetings, expositions, events, and conventions: An introduction to the industry, (4th ed.), New York, Pearson.

Geić, S. (2011), Menadžment selektivnih oblika turizma, Sveučilišni studijski centar za stručne studije, Split.

Gračan, D. (2020), "Research of Tourist motivations and activities in continental Tourism destinations", International Scientific Conference on Economic and Social Development, Vol. 53, pp. 8-18.

Gračan, D., Barkiđija Sotošek, M. and Šerić, N. (2018), "Changing trends in incentive travel", 24th Biennial International Congress Tourism \& Hospitality Industry 2018: Trends and Challenges, Vol. 24, pp. 98-109. 
ToSEE - Tourism in Southern and Eastern Europe, Vol. 6, pp. 315-327, 2021.

D. Gračan, M. Barkiđija Sotošek, R. Matošević: ASSESMENT OF CONVENTION PARTICIPANTS' ...

Gračan, D., Barkiđija Sotošek, M. and Torbarina, M. (2021), "The effect of the convention specific dimensions on universities teaching staff behavioral intention", Tourism and Hospitality Management, Vol. 27, No. 1, pp. 99-118

Lucianović, L. (1980), Kongresni turizam, Svjetlost, Sarajevo.

Rogers, T. (2008), Conferences and Conventions, Butterworth-Heinemann, Oxford.

Soldić, M. (n.d.), Poslovni i kongresni turizam donose četvrtinu ukupnog međunarodnog turizma. A gdje je Hrvatska?, Lider, viewed 03 November 2018, http://lider.media/aktualno/tvrtke-i-trzista/poslovnascena/poslovni-i-kongresni-turizamdonose-cetvrtinu-ukupnog-medunarodnog-turizma-a-gdje-jehrvatska/

Swarbrooke, J. and Horner, S. (2001), Business Travel and Tourism, Butterworth-Heinemann, Oxford.

Virgil, N. and Popsa, R.E. (2014), "Business Tourism Market Developments", Procedia Economics and Finance, Vol. 16, pp. 703-712.

World Tourism Organization and European Travel Commission (2015), The Decision-making Process of Meetings, Congresses, Conventions and Incentives Organizers, viewed 07 April 2020, https://www.unwto.org/archive/global/publication/decision-making-process-meetings-congressesconventions-and-incentives-organizers

World Tourism Organization (2006), Measuring the Economic Importance of the Meetings Industry Developing a Tourism Satellite Account Extension, viewed 07 April 2020, https://www.eunwto.org/doi/pdf/10.18111/9789284411955

Daniela Gračan, PhD, Full Professor

University or Rijeka, Faculty of Tourism and Hospitality Management

Department of Tourism

Primorska 46, 51410 Opatija, Croatia

+385-51-294718

danielag@fthm.hr

Marina Barkiđija Sotošek, PhD, Senior Assistant

University or Rijeka, Faculty of Tourism and Hospitality Management

Department of Tourism

Primorska 46, 51410 Opatija, Croatia

+385-51-294718

marinab@fthm.hr

Rea Matošević, MSc, MICE Sales Representative

Valamar Riviera d.d.

Stancija Kaligari 1, 52440 Poreč, Croatia

+385-99-461046

rea.matosevic96@gmail.com 